\title{
Prevalence of dental caries and anterior teeth malrelation to children with Down's syndrome in Makassar \\ Prevalensi karies gigi dan malrelasi gigi anterior pada anak penderita sindroma Down di Makassar
}

\author{
${ }^{1}$ Harun Achmad, ${ }^{1}$ Dian Eka K, ${ }^{2}$ Stefani Wijaya \\ ${ }^{1}$ Departement of Pediatric Dentistry \\ ${ }^{2}$ Clinical Student \\ Faculty of Dentistry, Hasanuddin University \\ Makassar, Indonesia
}

\begin{abstract}
ABSTRAK
Sindroma Down merupakan kelainan genetik autosomal yang sering terjadi dan disebabkan oleh kelainan kromosom trisomi 21. Kelainan ini menyebabkan ketidakmampuan dalam segala hal, termasuk menjaga kebersihan rongga mulut sehingga masalah dalam rongga mulut tidak dapat dihindari. Tujuan penelitian ini adalah untuk mendeskripsikan prevalensi karies gigi dan malrelasi gigi anterior anak sindroma Down di Makassar. Sampel penelitian berjumlah 46 anak penderita sindroma Down yang bersekolah di empat sekolah luar biasa (SLB), yaitu SLB-C Pembina Tingkat Provinsi, SLB-C Katolik Rajawali, SLB-D Yayasan Pembinaan Anak Cacat, dan SLB Prima Karya Antang, yang telah ditentukan dengan teknik purposive sampling. Kepada setiap sampel dilakukan pemeriksaan klinis dengan pendekatan crossed-sectional. Setiap sampel dicatat kondisi karies dalam rongga mulutnya dengan indeks penilaian DMF-T, dan dinilai relasi gigi anterior secara klinis, berupa anterior openbite, crossbite, edge to edge, labioversi, crowded, dan relasi normal. Hasil penelitian menunjukkan angka prevalensi karies gigi yang cukup tinggi ditemukan pada anak sindroma Down di Makassar, yaitu sebesar 82,6\% dengan nilai DMF-T rata-rata 3,69. Menurut interpretasi WHO, nilai tersebut termasuk kategori sedang. Relasi gigi anterior yang paling sering dialami adalah labioversi dengan persentase 28,27\%. Disimpulkan bahwa anak penderita sindroma Down di Makassar memiliki prevalensi yang tinggi untuk mengalami karies gigi dan labioversion relation.
\end{abstract}

Kata kunci: sindroma Down, karies gigi, malrelasi gigi anterior

\begin{abstract}
This study aimed to describe the prevalence of dental caries and malrelation of anterior teeth of Down's syndrome children in the city of Makassar. The samples were 46 Down's syndrome children who attended schools for handicapped children or Sekolah Luar Biasa (SLB), namely SLB-C Pembina Tingkat Provinsi, SLB-C Catholic Rajawali, SLB-D YPAC, and SLB Prima Karya Antang, selected by purposive sampling technique. Each sample was examined clinically by crossed-sectional approach. Condition of caries was recorded with the DMF-T index. Clinical observation of anterior teeth including anterior openbite, crossbite, edge to edge, labioversion, crowded was also done. The results show that the prevalence of dental caries among the Down's syndrome children in Makassar is $82.6 \%$, the mean of DMF-T scores is 3.69. According to the interpretation of the WHO, this belongs to moderate category. The most significant relation is labioversion as with $28.27 \%$. Our results show that Down's syndrome children in Makassar have a high prevalence dental caries, with the most significant malrelation is labioversion.
\end{abstract}

Key words: Down's syndrome, dental caries, anterior teeth malrelation

Koresponden: Harun Achmad, Bagian Ilmu Kedokteran Gigi Anak, Fakultas Kedokteran Gigi Universitas Hasanuddin, Jl. Perintis Kemerdekaan Km.10, Makassar, Indonesia. E-mail: harunachmad@yahoo.com

\section{INTRODUCTION}

Childhood was an extremely crucial in the development of an individual. The need for adequate and balanced nutrition is their capital to achieve an optimal level of development. However, not all children are born perfect. Some are born with abnormalities in the womb, some get the abnormalities from childbirth process, and some also get the abnormalities since toddler. One of them is Down's syndrome.

The name of Down's syndrome (DS) came from an English doctor, named Langdon Down.
Actually, DS is not a disease, but it is a genetic disorder which happens to man and woman. This disorder is a result from chromosome abnormality which is not always downed to the next generation. Abnormality of chromosome which is found frequently is the excess of 21 chromosomes named trisomy $21 .{ }^{1}$

The frequency of DS patient that happens in Indonesia is 1 in 600 living births. The number of DS case related with the age of pregnant woman. The ratio of incidence to the young mother aged less than 20 years old is 1:2000 for each birth. The 
frequency will increase to $1: 100$ at the age above 45 years old. The increasing age of the pregnant mother up above 45 years old will increase the risk of giving birth to a child with DS by 1:50. ${ }^{1}$

The people with DS have no mouth cavity problem is unique. However, several problems tend to occur and it could be worse. The early professional caring and daily caring at home can reduce the severity and make the patient of DS improve the health of oral cavity. ${ }^{2}$

Some of the researches reveal that caries in DS patient is not a problem because the incidence tends dental caries less than the children who have no DS. ${ }^{1,3,4}$ This is due to the excess of saliva (table 1), and particularly by the content of carbonate to the saliva so that it has a good buffer power. Besides, it is also microdontia and diastema condition that provides a role in tooth self cleansing effort. ${ }^{1}$ Moreover, there are some conditions of mouth relates to this, that there is an eruption from the primary and permanent teeth, the loss of permanent teeth, and the presence of a small tooth shape so that it makes a large diastema among teeth, which can make it easy to control and let plaque. In addition, there is a controlling food (diet) to most of DS children in preventing obesity, it can help reduce the food and cariogenic drink consumption. ${ }^{2}$

Nevertheless, there are some researchers state that mental retardation patient (Down's syndrome) has high tooth caries incidence, ${ }^{5,6}$ particularly to mental retardation and worst retardation. High caries incidence in mental retardation patient may be due to inability to do mouth cavity cleansing, or the parents pay less attention to their children's diet. $^{\text {? }}$

In addition to the problem of dental caries, the presence of malocclusion which is influenced by several factors, such as the existence of delayerupted permanent teeth, developmental disorder in maxilla, bad habits (breathing through the mouth, bruxism, and tongue trusting), abnormal teeth shape, unwell chewing, hypotonic muscles in oral cavity, and occurrence of anodontia partialis with incidence by $50 \%$ if compared to the general population, which is amounted to only $2 \%$. The only teeth that have not experienced anodontia are the permanent first molar. ${ }^{1,2,8,9}$

\section{Down's syndrome}

Down's syndrome is a retardation condition in physical and mental development of children due to an abnormality of chromosome development. DS, which is also famous with Trisomy 21, a disorder of chromosome is not a disease, but it is a genetic disorder which happens to people. Trisomy 21 is usually called as Down's syndrome because it was identified firstly in 1966 as a specific condition by John Langdon Down, a doctor in England. ${ }^{1,11,12}$

Down's syndrome is a genetic disorder which happens frequently. Occurrence frequency of DS children in Indonesia is 1 in 600 living births. ${ }^{1}$ In the world all prevalence is 10 DS per 10.000 living births, though in recent years this figure has increased. For the most part, the prevalence depends on several sociocultural variables. In countries where abortion is illegal such as Ireland and the United Arab Emirates, the prevalence is higher. In reverse, in France, the prevalence is low and this may be due to the high percentage of DS pregnancy termination. In Netherland, the most recent prevalence of DS is 16 per 10.000 living births. In UK, the prevalence of DS pregnancy has increased significantly, but there has been no change in the overall living births from DS. ${ }^{10}$ Occurrence number of DS is related to mother's age in pregnancy. The higher the maternal age at pregnancy, the greater the risk of bearing DS. ${ }^{13}$

The direct cause of DS is the excess of chromosome 21. Trisomy 21 can occur in one of three forms: (a) failure of separation in meiosis. An

Table 1 Characteristics of DS children ${ }^{1}$

\section{Extra oral}

1. Mentally retarded category of moderate to severe.

2. Generally of short stature with short neck and bent.

3. Face shape is more toward rounded with brachicephalic head. Base of the nose is wide and flat. Hairs look rare and fine.

4. Crease of the eye found epicantus and white spots on the iris, called brushfield spots, strabismus, nystagmus, refractive disorders, and congenital cataracts.

5. Palms only have one hand line across with short and wide finger, called simian crease.

\section{Intra oral}

1. The palate is reduced in length, width, and height, so it seems in the form of stairs or it can be V shape.

2. Orbicularis muscle is hypotonus, zygomaticus, massetter, and temporal cause the corners of the mouth drop and open the mouth.

3 . Tongue enlarged or macroglossia and fissurated on $2 / 3$ anterior of dorsal surface.

4. Abnormalities of teeth such as microdonsia, anodontia partialis, taurodontia.

5. Periodontal diseases can occur since 6 years old.

6. Caries incidence to the DS patient is caused by good hypersalivation and saliva buffer effect. 
Table 2 Prevalence formulas

\begin{tabular}{cc}
\hline The formula & The equation \\
\hline The prevalence of caries $=$ & $\frac{\text { Sum of children with caries } \times 100 \%}{\text { Total of children examined }}$ \\
The prevalence of anterior tooth relation $=$ & $\frac{\text { Sum children with anterior teeth relation condition }}{\text { Total of children examined }} 100 \%$ \\
\hline
\end{tabular}

error occurs on the separation of the pair of chromosome 21 during cell division in the process of formation of sperm and ovum cell. A child with DS has 47 chromosomes differently in each cell. This is the most often type. About $95 \%$ of DS, (b) translocation. About 3\% of DS. This happens if one of the excess of chromosome 21 is translocated to another chromosome. The other chromosomes may be chromosomes 13, 14, 15, and 22. There are 46 chromosomes in each cell, plus the excess of chromosome 21 attach to another chromosome, and (c) mosaic. Only about $2 \%$. Mosaic DS (46,XX/47, $X X, 21)$ happen when some cells are normal in the body and other cells are trisomy $21 .^{11}$

\section{Dental caries}

Caries is a disease of dental hard tissue, email, dentin, and dementum, caused by the activity of microorganisms ferments carbohydrates, signed by the demineralization of dental hard tissue which are followed by destruction of the organic material. ${ }^{14}$ In developing countries, the prevalence of dental caries continue to decline, whereas in developing countries including Indonesia, there is a tendency to increase in the prevalence of the disease.

\section{Anterior teeth relation}

Teeth relation is an upper and lower teeth relation in occlusive condition. Anterior teeth relation is checked by sagital and vertical aspect. The normal tooth relation on sagital aspect is the existence of over jet. On vertical aspect is the existence of overlapping bite/overbite which is a vertical overlap of the incisors. Overbite is measured by vertical distance clinically between upper incisors incisal and lower incisors incisal, the normal size is $2 \mathrm{~mm} .{ }^{15}$

Therefore, this article will describe more about the prevalence of dental caries and the relation of anterior teeth to DS children in Makassar, which has the largest population in South Sulawesi with the number of high dental caries.

\section{MATERIALS AND METHODS}

This research used a cross-sectional study design. It is carried out in Makassar. Samples were taken from four schools for handicapped children or Sekolah Luar Biasa (SLB), by using purposive sampling method. Sorted sample was determined based on consideration of researcher, covered population, completed age criteria, 6-20 years old, and quite cooperative. Samples were taken from the schools based on compass point. North point was represented by School of Yayasan Pembinaan Anak Cacat (YPAC). The east was represented by School (SLB-C) of Catholic Rajawali Yayasan Joseph. The south was represented by School of Pembina Tingkat Provinsi SLB-C. And, the west point was represented by School of Prima Karya Antang, Makassar.

In this study, intra oral examination was conducted clinically, then the caries condition was recorded in oral cavity, measured with prevalence formula (table 2) and analyzed according to the DMF-T index as well as see the anterior teeth relation clinically, in the form of open bite anterior, cross bite, edge to edge, labioversion, crowding, and normal relation.

\section{Study analysis}

WHO states the status category according to the DMF-T score as showd at table 3.

Table 3 Status category according to DMFT-score

\begin{tabular}{lc}
\hline Status category & DMFT-score \\
\hline Lowest & $0.0-1.1$ \\
Low & $1.1-2.6$ \\
Moderate & $2.7-4.4$ \\
High & $4.5-6.5$ \\
Highest & $>6.6$ \\
\hline
\end{tabular}

Anterior teeth relation means that open bite anterior is in vertical aspect, the lower incisors teeth untouched the upper incisors teeth and these are not occluded when posterior teeth are occlude, cross bite anterior is the relation of labiaolingual from anterior teeth that face each other opposed to its normal state, edge to edge is malocclusion that signed by the occlusion of upper and lower incisors teeth to its insisal corner and non-overlap, labioversion is an anterior teeth relation where maxilla anterior teeth protrusion, crowding is an anterior teeth relation in which case the relationship mess and crammed due to mesiodistal dimensions are not proportional overall from teeth 
with maxilla and mandible size, while normal relation is an anterior teeth relation where relation of ideal occlusion happens. ${ }^{16,17}$

\section{RESULTS}

From a study of DS children in Makassar, the obtained results are shown in Tables 4, 5, 6, 7, 8, $9,10,11,12$ and 13 .

Tabel 4 Distribution of the samples by gender

\begin{tabular}{ccc}
\hline Gender & Total (Person) & Percentage (\%) \\
\hline Male & 24 & 52.17 \\
Female & 22 & 47.83 \\
\hline Total & 46 & 100.00 \\
\hline
\end{tabular}

Tabel 5 Distribution of the samples by age

\begin{tabular}{ccc}
\hline Age (Year) & Total (Person) & Percentage (\%) \\
\hline $6-8$ & 4 & 8.70 \\
$9-12$ & 16 & 34.78 \\
$13-16$ & 14 & 30.43 \\
$17-20$ & 12 & 26.09 \\
\hline Total & 46 & 100.00 \\
\hline
\end{tabular}

Tabel 6 Distribution of the sample based on the school

\begin{tabular}{ccc}
\hline School & $\begin{array}{c}\text { Total } \\
\text { (Person) }\end{array}$ & $\begin{array}{c}\text { Percentage } \\
(\%)\end{array}$ \\
\hline SLB Pembina & 21 & 45.65 \\
Tingkat Provinsi & & \\
SLB-C Katolik & 9 & 19.57 \\
Rajawali & 8 & 17.39 \\
SLB-D YPAC & 8 & 17.39 \\
SLB Prima Karya & 8 & 100,00 \\
\hline Antang & 46 & \\
\hline Total & &
\end{tabular}

Tabel 7 Caries prevalence by age

\begin{tabular}{ccccc}
\hline Age (Year) & \multicolumn{2}{c}{ Yes } & \multicolumn{2}{c}{ No } \\
& $\mathrm{n}$ & $\%$ & $\mathrm{n}$ & $\%$ \\
\hline $6-8$ & 4 & 8.70 & 0 & 0,00 \\
$9-12$ & 14 & 30.49 & 2 & 4.35 \\
$13-16$ & 10 & 21.74 & 4 & 8.70 \\
$17-20$ & 10 & 21.74 & 2 & 4.35 \\
\hline Total & 38 & 82.60 & 8 & 17.40 \\
\hline
\end{tabular}

Tabel 8 Caries prevalence by gender

\begin{tabular}{ccccc}
\hline \multirow{2}{*}{ Gender } & \multicolumn{2}{c}{ Yes } & \multicolumn{2}{c}{ No } \\
& $\mathrm{n}$ & $\%$ & $\mathrm{n}$ & $\%$ \\
\hline Male & 17 & 36.95 & 7 & 15.22 \\
Female & 21 & 45.65 & 1 & 2.18 \\
\hline Total & 38 & 82.60 & 8 & 17.40 \\
\hline
\end{tabular}

Tables 4,5 , and 6 show that DS children in Makassar are more in male (52.17\%), in about 9-12 years old (34.68\%) and most of them are students at School of Pembina Tingkat Provinsi (45.65\%).
While tables 7, 8 , and 9 show that caries prevalence to DS children in Makassar is quite high $(82.6 \%)$. Tables 10, 11 and 12 ilustrate the caries status in average of DS children in Makassar is classified as moderate according to WHO by the carries index score average of $3.69 \%$.

Tabel 9. Caries prevalence based on the school

\begin{tabular}{ccccc}
\hline School & \multicolumn{2}{c}{ Yes } & \multicolumn{2}{c}{ No } \\
& $\mathrm{n}$ & $\%$ & $\mathrm{n}$ & $\%$ \\
\hline SLB Pembina & 19 & 41.30 & 2 & 4.36 \\
Tingkat Provinsi & 19 & & & \\
SLB-C Katolik & 6 & 13.04 & 3 & 6.52 \\
$\quad$ Rajawali & & 17.39 & 0 & 0.00 \\
SLB-D YPAC & 9 & 5 & \\
SLB Prima & 5 & 10.87 & 3 & 6.52 \\
Karya Antang & 38 & 82.6 & 8 & 17.40 \\
\hline Total & 38
\end{tabular}

Tabel 10 DMF-T index of caries by age

\begin{tabular}{ccc}
\hline Age (Year) & Mean & Caries Status \\
\hline $6-8$ & 2.25 & Low \\
$9-12$ & 3.12 & Moderate \\
$13-16$ & 3.57 & Moderate \\
$17-20$ & 5.08 & High \\
\hline Average & 3.69 & Moderate \\
\hline
\end{tabular}

Tabel 11 DMF-T index of caries by gender

\begin{tabular}{ccc}
\hline Gender & Mean & Caries Status \\
\hline Male & 2.92 & Moderate \\
Female & 4.54 & High \\
\hline Total & 3.69 & Moderate \\
\hline
\end{tabular}

Tabel 12 DMF-T caries index based on school

\begin{tabular}{cccc}
\hline School & $\begin{array}{c}\text { Total } \\
\text { (Person) }\end{array}$ & Mean & $\begin{array}{c}\text { Caries } \\
\text { Status }\end{array}$ \\
\hline SLB Pembina & 21 & 4.67 & High \\
Tingkat Provinsi & & & Moderate \\
SLB-C Katolik & 9 & 2.56 & Moderate \\
Rajawali & 8 & 3.75 & Low \\
SLB-D YPAC & 8 & 2.38 & Loderate \\
SLB Prima Karya & 8 & 3.69 & Moderang \\
Antang & 46 & & \\
\hline Average & & & \\
\hline
\end{tabular}

Table 13 shows that most DS children found in Makassar have anterior teeth relation are labioversion with the percentage of $28,27 \%$.

\section{DISCUSSION}

Based on the observations of researcher in the field, there are two influential factors to the high incidence of caries in DS children in Makassar, the environmental factors and psychological factors of the children. Environment is a place that supports 
Tabel 13 Distribution of the sample based on the relation of anterior teeth

\begin{tabular}{ccccccc}
\hline Anterior Teeh Relation & \multicolumn{2}{c}{ Male } & \multicolumn{2}{c}{ Female } & \multicolumn{2}{c}{ Total } \\
& $\mathrm{n}$ & $\mathrm{N}$ & $\mathrm{n}$ & $\%$ & $\mathrm{n}$ & $\%$ \\
\hline Open bite & 5 & 10.87 & 3 & 6.52 & 8 & 17.39 \\
Cross bite & 2 & 4.34 & 4 & 8.70 & 6 & 13.04 \\
Edge to edge & 3 & 6.52 & 5 & 10.87 & 8 & 17.39 \\
Labioversion & 9 & 19.57 & 4 & 8.70 & 13 & 28.27 \\
Crowding & 4 & 8.70 & 2 & 4.34 & 6 & 13.04 \\
Normal & 1 & 2.17 & 4 & 8.70 & 5 & 10.87 \\
\hline Total & 24 & 52.17 & 22 & 47.83 & 46 & 100.00 \\
\hline
\end{tabular}

the development of the child, not least DS children. Environment in question is the child's own family. Down's syndrome children in desperate need of help families, particularly parents in the process of growth and development for children born with any inability to fend for themselves, not least in terms of oral and dental care that relies heavily on parents. This is where the role of environment in this case the parents to give special attention to the children to maintain oral and dental health early on, so caries problem can be avoided. However, it seems in the city of Makassar in particular, the children needs of environmental and more attention for DS is not well fulfilled. Many parents do not understand the importance of oral and dental health of children. This point can be shown from the high incidence of caries at DS children in the city Makassar, whereas in some countries, the reverse of caries incidence is due to better condition of environmental and hypersalivation condition of DS children that can prevent the caries occurrence. Therefore, the provision of education about the importance of early prevention is required and the importance of visiting dentist on a regular basis (34 months) and at least once in every 6 months and do not forget to help clean the children teeth every day.

In addition to environmental factors, there are also psychological factors in children turned out to give obstacle in the functioning of environmental barriers as well. This is because DS children are not cooperative and the level of intelligence and mental are low. According to observation by researcher, DS children tend to have a shy nature and will not show the condition of oral cavity to dentist or family, making it difficult for the maintenance of teeth and mouth, either by way of professional treatments or daily care by family. If this continues, caries disease will not be prevented. Therefore, in responding to and dealing with DS children, it is required patience and hard work of families and the perpetrators of healthcare for the creation of children oral health.
Based on observations during the field study, researcher did not find the influence of socioeconomic factors on quite a high incidence of caries as DS children who have education in school are quite elite (completed facilities) and discipline can be found in children with caries. It demonstrates the role of facilities in terms of prevention of dental caries to DS children in the city of Makassar.

Besides the problem of caries, the DS children also found the condition of malrelation of the teeth, especially anterior to disrupt the aesthetic and the process of mastication. It can be caused by some factors, such as the existence of permanent teeth eruption delayed, some developmental disorders in maxilla, bad habits (breathing through the mouth, bruxisms, and tongue trusting), abnormal teeth (microdonsia and anodonsia partial). ${ }^{1}$ The latter factor is one of the factors that plays a role in preventing the occurrence of caries because of its role in facilitating plaque control. ${ }^{2}$ However, it is also useless if it is not backed up by a factor of oral hygiene and good environment. On the contrary it may cause other problems in the oral cavity, a condition of malrelation to DS children's teeth for his role in creating the space among the teeth so the teeth are not in normal relations. This can be seen in table 10, which defines the relationship of DS children's anterior teeth with labioversion anterior teeth. The result indicates bad habits in breathing through the mouth and thumb sucking is a factor that mostly contributed to the teeth malrelation occurrence in the most DS in Makassar.

From the discussion about result of study about prevalence of dental caries and anterior teeth malrelation to children with Down's syndrome in Makassar, it is concluded that DS children in Makassar have a quite caries prevalence $(82.6 \%)$, categorized as moderate by WHO (36.9\%) and have the most anterior teeth relation as labioversion $28.27 \%$. Furthermore, external factors have more effect on oral and dental health to Down's syndrome children in city of Makassar compared to internal factors. 
The need for mouth and teeth health education to families with Down's syndrome about the importance of child oral hygiene maintenance, as well as the need for further research with larger samples in order to obtain better and more accurate results.

\section{REFERENCES}

1. Sudiono J. Manifestasi oral sindroma down. J Indonesian Dent Assoc 2005;55(1):23-7.

2. US Department of Health and Human Services. Practical oral care for people with development disabilities. [serial online] 2007. [internet]. Available from URL: http://nccanch.afc.hhs.gov. Accessed December 15, 2011.

3. Asokan S. Muthu MS, Sivakumar N. Dental caries prevalence and treatment needs of Down's syndrome children in Chennai, India. Indian J Dent Res 2008; 19(3): 224-9.

4. Areias CM, Maia BS, Guimaraes H, Melo P, Andrade D. Caries in Portuguese children with Down's syndrome. Clin 2011; 66(7): 1183-6.

5. Oredugba FA. Oral health condition and treatment needs of a group of Nigerian individuals with Down's syndrome. Down Syndrome Res Prac 2007; 12(1): 72-7.

6. Al-Khadra TA. Prevalence of dental caries and oral hygiene status among Down's syndrome patients in Riyadh - Saudi Arabia. Pakistan Oral \& Dent J 2011; 31(1): 115-7.

7. Sungkar S. Perawatan gigi dan mulut pada anak retardasi mental. Cakradonya Dent J 2009; 1: 47-54.

8. Perez RL, Yanez SA, Morales PL. Anterior open bite and speech disorders in children with Down syndrome. Angle Orthodont 2008: 221-7.

9. Mestrovic S, Miksic M, Papic JC, Stipetic J. Prevalence of malocclusion in patients with Down's Syndrome. Acta Stomatol Croat 2002; 239-41.

10. Weijerman M. Consequences of Down's syndrome for patient and family. Amsterdam : Ipskamp Drukkers B.V.; 2011. p. 13, $15,17$.

11. Guralnick MJ. Clinical practice guideline report of the recommendations Down's syndrome assessment and intervention for young children (age 0-3 years old). New York: New York State Department of Health; 2000. p. $14-20$.

12. McDonald RE, Avery DR, Dean JA. Dentistry for the child and adolescent. $8^{\text {th }}$ Ed. Philadelphia: Mosby; 2004. p. 542.

13. Stewart KB. Trisomy 21-Down's syndrome. The australasian genetics resource book; 2007: 28. [internet]. Available from URL: www.genetics.edu.au. Accessed December 26, 2011.

14. Cahyati WH. Karies gigi pada anak TK (studi kasus di Kecamatan Tembalang Kota Semarang). Kesehatan Masyarakat 2008; 4(1):14-24.

15. Rahardjo P. Diagnosis ortodontik. Surabaya: Airlangga University Press; 2008. p. 63-8; 79-80.

16. Ogston R, Harty FJ. Kamus kedokteran gigi. Alih bahasa: Narlan S. Jakarta: EGC; 1995. p. 214-5.

17. Mills LF. Epidemiologic studies of occlusion IV the prevalence of malocclusion in a population of 1,455 school children. J Dent Res 1966; 332-6. 